\title{
PENGEMBANGAN PERANGKAT PEMBELAJARAN BERDASARKAN MASALAH BERBASIS EDUTAINMENT UNTUK MELATIHKAN KREATIVITAS SISWA SMK JURUSAN OTOMOTIF PADA MATERI FLUIDA STATIS
}

\author{
Mohammad Ali Sofyan" ${ }^{1)}$, Wasis ${ }^{2)}$, Muslimin Ibrahim ${ }^{3)}$ \\ ${ }^{1)}$ Program Studi Pendidikan Sains, Program Pascasarjana Universitas Negeri Surabaya, \\ ${ }^{2)}$ Dosen Program Studi Pendidikan Sains, Program Pascasarjana Universitas Negeri Surabaya \\ ${ }^{3}$ Dosen Program Studi Pendidikan Sains, Program Pascasarjana Universitas Negeri Surabaya \\ Email:mohammadalisofyan@gmail.com
}

\begin{abstract}
Abstrak: Penelitian ini bertujuan untuk menghasilkan perangkat pembelajaran fisika model pembelajaran berdasarkan masalah (PBM) yang valid, praktis, dan efektif untuk melatihkan kreativitas siswa. Penelitian ini dilaksanakan dengan menggunakan tiga tahap dari model 4-D, yaitu tahap pendefinisian (define), perancangan (design), dan pengembangan (develop) dan diujicobakan di kelas XI SMK Senopati Sedati Sidoarjo jurusan otomotif pada materi fluida statis semester ganjil tahun pelajaran 2016/2017 dengan rancangan one group pretest-posttest design. Perangkat pembelajaran yang dikembangkan meliputi: (a) silabus (b) RPP, (c) handout, (d) LKS, dan (e) lembar penilaian kreativitas. Variabel penelitian yang diukur adalah validitas, kepraktisan dan keefektifan perangkat pembelajaran. Data penelitian diperoleh melalui metode validasi, observasi, tes, dan angket. Hasil penelitian dianalisis secara deskriptif kuantitatif dan kualitatif.. Hasil penelitian menunjukkan bahwa (a) perangkat pembelajaran yang dikembangkan berkategori valid, (b) keterlaksanaan pembelajaran berjalan dengan baik, (c) pelatihan kreativitas siswa menghasilkan peningkatan dengan kategori sedang, serta (d) siswa memberikan respon positif terhadap pembelajaran yang sudah dilaksanakan. Berdasarkan hasil analisis dan pembahasan, disimpulkan bahwa perangkat fisika model pembelajaran berdasarkan masalah (PBM) berbasis edutainment yang telah dikembangkan valid, praktis, dan efektif untuk melatihkan kreativitas siswa.
\end{abstract}

Kata-kata kunci: edutainment, model PBM, kreativitas siswa.

\begin{abstract}
The purpose of this research is to produce a Physics learning materials using Problem Based Instruction (PBI) model, which is valid, practical, and effective to Train creativity of student. This research is conducted through three phases from 4-D model, those are define, design, and develop. That instrument is tried out in XI grade Vocation High School of Senopati Sedati Sidoarjo academic year 2016/2017 with one group pretest-post test design. The learning instruments developed include: (a) syllabus, (b) Lesson Plan, (c) handout, (d) Work Sheet, (e) Assessment Sheet of creativity. Research variabels which can be measured are validity, practicality, and effectiveness of learning instrument. Data are collected using validity method, observation, test, questionnaires. Data are analyzed quantitatively descriptive and qualitatively. Research data shows that (a) developed learning instrument is categorized valid, (b) Learning process was going well, (c) training of student creativity produces increase on middle category, and (d) student gives positive feedback to learning had done. Based on analysis and discussion, concluded that Physics learning instrument using model of PBI based on education developed is valid, practical, and effective to train creativity of student.
\end{abstract}

Key words: edutainment, PBI model, creativity of student

\section{PENDAHULUAN}

Pendidikan adalah salah satu aspek yang sangat penting dalam kehidupan manusia. Upaya meningkatkan kualitas pendidikan terus-menerus dilakukan secara inovatif. Pendidikan diharapkan dapat meningkatkan kreativitas dalam pemecahan suatu masalah. Kreativitas dibutuhkan untuk menghadapi perubahanperubahan global dan persaingan pasar bebas, serta tuntutan kemajuan ilmu pengetahuan dan teknologi. 
Artinya seseorang yang memiliki kreativitas akan mampu untuk menghadapi perkembangan teknologi dan memecahkan masalah. Kreativitas dipengaruhi oleh faktor lingkungan, baik di lingkungan keluarga, sekolah, atau masyarakat (Hurlock, 1978, p.7).

Sekolah sebagai sebuah masyarakat kecil (mini society) yang merupakan wahana pengembangan siswa, dituntut untuk menciptakan iklim pembelajaran yang demokratis (democratic instruction), agar terjadi proses belajar yang menyenangkan (joyfull learning). Pembelajaran seperti itu diharapkan dapat melahirkan siswa yang mandiri, kritis, rasional, cerdas, kreatif, dan siap menghadapi berbagai macam tantangan.

Kenyataannya banyak siswa yang tidak siap menghadapi tantangan dunia nyata karena tidak tahu manfaat dari pembelajaran di sekolah dalam kehidupan mereka. Hal ini disebabkan karena masih rendahnya tingkat kreatifitas siswa. Data nilai kreatifitas siswa kelas XI TKR SMK Senopati tahun perajaran 2015/2016 menyatakan bahwa nilai kreatifitas siswa masih dibawah 70. Lulusan kita tidak mampu untuk menyelesaikan masalah karena melihat sesuatu secara segmented, sedangkan masalah nyata yang timbul di dunia pekerjaan selalu merupakan masalah kompleks yang merupakan gabungan dari banyak disiplin ilmu (Hamid, 2014).

Memasuki Abad ke-21 kehidupan menjadi lebih kompleks karena pesatnya perkembangan teknologi dan inovasi. Berdasarkan polling yang diadakan pada Tahun 2007 oleh Parthership for $21^{\text {st }}$ Century Skills, $80 \%$ respondennya menyatakan bahwa yang diperlukan siswa untuk dipelajari saat ini berbeda dengan kemampuan yang harus mereka pelajari 20 tahun yang lalu (Bob, 2008). Salah satu kemampuan tersebut adalah kreativitas. Siswa perlu dibekali dengan kemampuan memecahkan masalah dan berpikir kreatif agar potensi kreativitas siswa dapat optimal sehingga siswa benar-benar siap menghadapi tantangan di Abad ke-21.

Beberapa negara barat seperti Amerika Serikat, Inggris, Perancis, Jerman, Swedia, dan Australia telah mengembangkan pendekatan baru dalam pendidikan untuk mempersiapkan generasi mereka. Reformasi kurikulum telah dilakukan dan kreativitas masuk ke dalam kebijakan pendidikan (Feldman dan Benjamin, 2006; Craft, 2005; Saheen, 2010; dalam Lin, 2011). Beberapa negara di Asia seperti Cina, Hongkong, Jepang, Korea Selatan, Taiwan, dan Singapura juga merespon perubahan tantangan dalam dunia pendidikan dengan mereformasi kurikulum pendidikannya dengan menekankan pada pengembangan kreativitas (Choe, 2006; Saheen, 2010; dalam Lin, 2011). Pemerintah Indonesia juga merespon dengan dilakukannya pembenahan kurikulum pendidikan dengan proses pembelajaran yang menekankan pada pemberian pengalaman langsung untuk mengembangkan kompetensi dan kreativitas, sehingga siswa dapat menjelajahi dan memahami alam sekitar secara ilmiah.

Kreativitas dapat didefinisikan sebagai suatu produk atau proses. Sternberg dan Lubart (dalam Lin,
2011) mendefinisikan kreativitas sebagai produksi kerja yang memiliki nilai kebaruan dan kebermanfaatan. Torrace (1965) memandang kreativitas sebagai hasil seseorang menjadi peka terhadap permasalahan, kekurangan, kesenjangan pengetahuan, ketidakserasian, mengidentifikasi kesulitan, mencari pemecahan masalah, dan mengkomunikasikan hasil. Berdasarkan uraian diatas maka kreativitas adalah suatu proses yang menghasilkan sesuatu yang baru, apakah suatu gagasan atau suatu objek dalam suatu bentuk atau susunan baru.

Guru juga dapat memenuhi kebutuhan siswa akan perkembangan kreativitas dengan lebih baik melalui metode pembelajaran yang tepat sehingga dapat memberikan kesempatan belajar yang dapat memfasilitasi berkembangnya kreativitas siswa. Siswa yang menjadi subyek ujicoba dalam penelitian ini adalah siswa kelas XI SMK. Menurut hasil survey di SMK Senopati menunjukkan beberapa siswa memiliki pandangan bahwa fisika sebagai pelajaran yang sulit dan membosankan. Secara psikologis siswa kurang tertarik dengan metode yang digunakan guru, maka berakibat siswa akan memberikan respon psikologis yang kurang mendukung proses pembelajaran. Indikasinya adalah timbul rasa tidak simpati terhadap guru, tidak tertarik dengan materi-materi pembelajaran, dan lama kelamaan akan timbul sikap acuh tak acuh terhadap mata pelajaran. Berdasarkan hasil survey di SMK Senopati siswa berharap pembelajaran fisika dikemas secara kreatif agar lebih menarik dan menyenangkan. Siswa juga berharap agar guru lebih aktif dalam memberikan bimbingan kepada siswa dengan materi bersifat kontekstual sehingga lebih bermanfaat dalam kehidupan sehari-hari.

Pembelajaran di sekolah seharusnya dapat membuat siswa senang dan tidak tertekan sehingga kreativitas siswa dapat meningkat, hal ini dapat dilakukan apabila guru menggunakan metode yang cocok dalam proses pembelajaran. Hasil penelitian Rozaq (2013) menyimpulkan bahwa penggunaan metode inkuiri pada materi optika geometri dapat meningkatkan kreativitas siswa.

Pembelajaran Berdasarkan Masalah (PBM) yang menekankan implementasi pada kehidupan nyata merupakan salah satu model pembelajaran yang harus dilakukan guru untuk membentuk siswa dalam menghadapi era globalisasi dan melatihkan kreativitas siswa. Siswa dapat dikatakan mencapai kreativitas apabila siswa peka terhadap permasalahan dan dapat mencari pemecahan masalah. PBM dirancang untuk membantu siswa mengembangkan keterampilan berpikir, keterampilan menyelesaikan masalah, dan keterampilan intelektualnya, mempelajari peran-peran orang dewasa dengan mengalami berbagai situasi riil dan menjadikan pelajar yang mandiri dan otonom sehingga diharapkan akan memperbaiki mutu pendidikan yang ada di Indonesia (Arends, 2008, p.43).

Hal ini menjadi tugas bagi guru untuk menerapkan dan mengembangkan model pembelajaran 
yang tepat dan menyenangkan bagi siswa, sehingga siswa merasa nyaman dan termotivasi untuk belajar. Siswa tidak hanya merasa senang dalam proses pembelajaran tetapi pembelajaran yang diberikan oleh guru seharusnya dapat melatihkan kreativitas siswa, oleh karena itu untuk mewujudkannya ada beberapa hal yang perlu di lakukan oleh guru, yaitu dengan cara menyajikan fenomena yang terjadi dalam kehidupan sehari-hari sebagai motivasi siswa, sehingga siswa merasa perlu untuk mempelajari materi yang akan diajarkan. Kedua, guru harus membuat suasana kelas yang nyaman, dengan menerapkan model pembelajaran yang tepat sehingga siswa tidak merasa bosan, dan model tersebut juga disertai dengan metode yang tepat untuk menunjang pembelajaran tersebut.

Pembelajaran berdasarkan masalah (PBM) yang memberikan permasalahan secara konkrit akan menimbulkan rasa ingin tahu siswa sehingga siswa lebih interaktif dan pembelajaran bisa berjalan secara optimal. Hasil penelitian Novianto (2014) menyimpulkan bahwa pembelajaran berdasarkan masalah dapat meningkatkan kecakapan akademik siswa dan keterampilan proses siswa. Sulardi (2014) menyimpulkan bahwa pembelajaran berdasarkan masalah dapat meningkatkan kemampuan berpikir kritis. Siburian (2012) menyimpulkan bahwa penerapan model pembelajaran berdasarkan masalah berpengaruh positif untuk meningkatkan penguasaan konsep fluida statis dan kemampuan berpikir kritis siswa.

Edutainment, sering dipanjangkan secara bergantian sebagai educational entertainment atau entertainment-education, adalah suatu bentuk entertainment yang dirancang untuk mendidik dan menarik perhatian siswa dengan cara-cara yang menghibur (Darmansyah, 2010). Program pendidikan atau pelatihan yang dikemas sedemikian rupa dalam konsep hiburan yang menarik, sehingga tiap-tiap siswa hampir tidak menyadari bahwa mereka sebenarnya sedang diajak untuk belajar atau untuk memahami materi pelajaran dan nilai-nilai untuk setiap individu. Landasan teori yang dapat menjadi pijakan pelaksanaan konsep edutainment ini adalah berdasarkan berbagai hasil penelitian, diyakini bahwa suatu materi pembelajaran harus didesain sedemikian rupa sehingga mengakomodasi tipe pembelajar, gaya belajar, serta menarik (Darmansyah, 2010).

Salah satu teori yang menjadi dasar dari pemikiran ini adalah dual coding theory. Menurut dual coding theory, informasi diproses melalui dua channel yang independent, yaitu channel verbal seperti teks dan suara, dan channel visual seperti diagram, animasi, dan gambar.

Penelitian lebih lanjut berkaitan dengan dual coding theory yang dilakukan oleh Paivio, Bagget (1989), dan Kozma (1991) mengindikasikan bahwa dengan memilih perpaduan media yang sesuai, hasil belajar dan kreativitas dari seseorang dapat ditingkatkan. Seperti yang telah diungkapkan Eric Jensen, menyatakan tiga unsur utama yang mempengaruhi proses belajar adalah keadaan, strategi, dan isi. Jadi, menciptakan suasana yang tepat untuk belajar, dengan menggunakan gaya atau metode pembelajaran yang baik, serta topik yang nyata dalam kehidupan sehari-hari sangat diperlukan dalam meningkatkan kreativitas siswa. Belajar hanya akan efektif jika suasana (suasana hati siswa) berada dalam kondisi yang menyenangkan (Darmansyah, 2010, p.3).

Munculnya konsep edutainment, yang mengupayakan proses pembelajaran yang kondusif dan menyenangkan, dengan asumsi: pertama, perasaan positif (senang/gembira) akan mempercepat pembelajaran; kedua, jika seseorang mampu menggunakan potensi nalar dan emosi secara baik, maka ia akan membuat loncatan prestasi belajar yang tidak terduga sebelumnya, ketiga, bila setiap pembelajar dapat dimotivasi secara tepat dan diajar dengan cara yang benar, cara yang menghargai gaya belajar dan modalitas mereka, mereka semua akan dapat mencapai hasil belajar yang optimal (Hamid, 2011).

Penelitian lebih lanjut pada pembelajaran yang menyenangkan khususnya pada materi fluida statis pada siswa SMK jurusan otomotif untuk melatihkan kreativitas dalam memecahkan masalah menggunakan model pembelajaran berdasarkan masalah berbasis edutainment perlu untuk dilaksanakan. Peneliti mengharapkan mata pelajaran fisika khususnya pada materi fluida statis dapat mengintegrasikan sikap, pengetahuan dan keterampilan dalam kegiatan penyelidikan untuk memecahkan masalah. Model Pembelajaran Berdasarkan Masalah (PBM) berbasis Edutainment dapat mempermudah siswa memahami dan menyelesaikan permasalahan fisika.

Berdasarkan permasalahan yang dipaparkan di atas peneliti tertarik untuk melakukan penelitian dengan judul "pengembangan perangkat pembelajaran berdasarkan masalah (PBM) berbasis edutainment untuk melatihkan kreativitas siswa SMK jurusan otomotif pada materi fluida statis"

\section{METODE}

Penelitian ini merupakan penelitian pengembangan. Penelitian ini mengembangkan perangkat model pembelajaran berdasarkan masalah pada materi fluida statis untuk melatihkan kreativitas siswa. Perangkat pembelajaran yang dihasilkan meliputi Rencana Pelaksanaan Pembelajaran (RPP), Lembar Kegiatan Siswa (LKS), handout materi fluida statis, instrumen penilaian dan instrumen tes kreativitas. Pengembangan perangkat pembelajaran dalam penelitian ini merujuk Nieveen (1999) juga mengadaptasi model 4D yang dikemukakan oleh Thiagarajan, et al. (1974). Proses pengembangan terdiri dari empat tahap, yaitu define (pendefinisian), design (perancangan), develop (pengembangan), dan disseminate (penyebaran). Hasil penelitian ini tidak disebarkan pada kelas lain atau sekolah lain (selain tempat penelitian) sehingga penelitian ini hanya menggunakan tiga tahap, yaitu define (pendefinisian), design (perancangan), develop (pengembangan). Pada tahap pendefinisian terdapat lima 
langkah pokok yaitu analisis kebutuhan, analisis siswa, analisis tugas, analisis konsep, dan perumusan tujuan. Selanjutnya pada tahap perancangan, peneliti menyusun RPP, Handout, LKS, Lembar penilaian, dan lembar pengamatan yang selanjutnya perangkat tersebut divalidasi oleh dua pakar ahli. RPP dikembangkan dengan pembelajaran berbasis edutainment. Tahap pengembangan dilakukan dengan memperbaiki perangkat pembelajaran sesuai dengan saran validator dan hasil ujicoba terbatas. Perangkat yang sudah diperbaiki kemudian diujicobakan pada kelas yang telah ditentukan.

Hasil validasi perangkat pembelajaran dari pakar ahli diujicobakan dengan rancangan penelitian onegroup pretest-posttest design. Ujicoba dilakukan di SMK Senopati kelas XI tahun ajaran 2016/2017. Ujicoba dilakukan untuk memperoleh informasi berupa keterlaksanaan pembelajaran, kreativitas siswa, dan respon siswa. Instrumen ujicoba berupa lembar pengamatan keterlaksanaan pembelajaran, lembar tes kreativitas, lembar respon siswa, dan lembar kendala pembelajaran.

Data yang diperoleh dianalisis secara deskriptif kuantitatif dan kualitatif. Data yang dihasilkan awalnya dianalisis secara deskriptif kuantitatif, selanjutnya hasil analisis data dijabarkan menggunakan analisis deskriptif kualitatif untuk memperoleh pernyataan yang menggambarkan kategori dari angka-angka yang diperoleh. Pengaruh pembelajaran terhadap kreativitas siswa, dapat diketahui dengan analisis statistik inferensial berupa $N$-gain score dengan rumus sebagai berikut:

$$
\langle g\rangle=\frac{\text { Spost }- \text { Spre }}{S \text { max }- \text { Spre }}
$$

dengan $\langle g\rangle=$ nilai gain, Spost $=$ nilai posttest , Spre $=$ nilai pretest, dan Smax = nilai maksimal.

\section{PEMBAHASAN}

\section{A. Validitas}

Penelitian ini merupakan penelitian pengembangan perangkat pembelajaran berbasis Edutainment pada materi fluida statis yang bertujuan untuk melatihkan kreativitas siswa SMK jurusan otomotif. Perangkat pembelajaran dapat dinyatakan layak apabila aspek kevalidan, kepraktisan, dan keefektifan terpenuhi (Nieeven, 2007). Perangkat pembelajaran yang telah dikembangkan berupa silabus, Rencana Pelaksanaan Pembelajaran (RPP), Handout, Lembar Kerja Siswa (LKS), serta instrumen tes kreativitas. Perangkat yang dikembangkan disesuaikan dengan Model Pembelajaran Berdasarkan Masalah (PBM).

Berdasarkan data hasil penelitian yang telah dipaparkan di bab IV, kevalidan perangkat pembelajaran ditinjau dari hasil validasi perangkat oleh dua pakar yang meliputi: silabus, RPP, handout, LKS, serta tes kreativitas siswa. Kepraktisan perangkat pembelajaran ditinjau dari keterlaksanaan rencana pelaksanaan pembelajaran.
Keefektifan perangkat pembelajaran ditinjau dari hasil tes kreativitas siswa saat pretest dan posttest dan respon siswa.

Perangkat pembelajaran yang telah dikembangkan kemudian divalidasi oleh dua orang validator. Secara umum perangkat pembelajaran yang dikembangkan mendapatkan hasil yang valid dan sangat valid dari validator. Silabus yang dikembangkan oleh peneliti merupakan silabus model pembelajaran berdasarkan masalah berbasis edutainment pada materi fluida statis. Silabus merupakan seperangkat rencana dan pengaturan tentang kegiatan pembelajaran, pengelolaan kelas, dan penilaian hasil belajar (Kardi, 2012). Sejalan dengan pernyataan tersebut, Supeno (2016) menyatakan bahwa silabus yang baik dapat dijadikan sebagai acuan dalam menyusun kerangka pembelajaran. Kerangka pembelajaran yang terdapat dalam silabus selanjutnya diwujudkan dalam bentuk RPP, Handout, LKS, dan lembar penilaian. Pernyataan tersebut mengindikasikan bahwa silabus merupakan dasar yang digunakan sebagai acuan dalam mengembangkan perangkat pembelajaran yang lainnya. Oleh karena itu, silabus yang dikembangkan harus berkategori valid.

Hasil validasi silabus oleh validator yang disajikan pada tabel 4.1 di bab IV menunjukkan bahwa komponen silabus mendapat skor rata-rata 3,69 dengan kategori sangat valid dengan rata-rata reliabilitas 92,4\% . Silabus ini dinyatakan valid karena komponen yang seharusnya ada dalam silabus terpenuhi, diantaranya identitas mata pelajaran, identitas sekolah, standar kompetensi, kompetensi dasar, indikator, materi pembelajaran, kegiatan pembelajaran, penilaian, alokasi waktu dan sumber belajar (permendikbud nomor 58 tahun 2014).

RPP yang dikembangkan pada penelitian ini juga merupakan RPP dengan model pembelajaran berdasarkan masalah berbasis edutainment pada materi fluida statis dengan tujuan meningkatkan kreativitas siswa SMK jurusan otomotif. Kegiatan pembelajaran yang termuat dalam RPP disesuaikan dengan sintaks model PBM berbasis edutainment. RPP yang dikembangkan terlebih dahulu divalidasi oleh dua validator sebelum diimplementasikan. Ada beberapa saran dari validator seperti yang telah dijelaskan pada bab IV yang dijadikan peneliti sebagai landasan untuk merevisi RPP agar dihasilkan RPP yang baik sebagai pedoman dalam mengelola kegiatan pembelajaran.

Hasil validasi RPP menunjukkan bahwa RPP yang telah dikembangkan dapat digunakan pada tahap uji coba. Hal ini karena rata-rata penilaian validasi RPP berupa format, isi dan bahasa sebesar 3,56 dengan kategori valid, dengan rata-rata reliabilitas dari ketiga komponen adalah 97\%. Pada permendikbud nomor 58 tahun 2014 menyatakan bahwa dalam penyusunan RPP harus memuat indikator dan tujuan pembelajaran, deskripsi materi ajar, penjabaran kegiatan pembelajaran, metode-model pembelajaran, penentuan alokasi waktu, alat dan sumber 
belajar seta pengembangan penilaian hasil belajar. Pada pembelajaran yang dilakukan dalam kelas maupun di luar kelas harus bisa menumbuhkan kreativitas siswa. Siswa diberikan kebebasan untuk mengutarakan idenya tanpa ada kritikan sehingga mereka tidak takut salah, ditertawakan, diremehkan, tertekan. Menciptakan suasana yang menyenangkan dapat dilakukan dengan membuat pembelajaran yang lebih rileks (tidak tegang), mengaitkan materi ajar dengan kehidupan nyata mereka, belajar dengan permainan yang menyenangkan, dorongan motivasi, dan pemberian jeda berpikir dan berpendapat.

Handout dan LKS yang dikembangkan untuk mendukung proses pembelajaran juga telah dinyatakan valid untuk digunakan pada tahap uji coba. Hal ini didukung oleh hasil validasi handout dari segi kelayakan isi, aspek bahasa dan penyajian. Berdasarkan pada tabel 4.4 bab IV handout yang dikembangkan mendapat skor rata-rata 3,59 dengan kategori valid, dengan reliabilitas rata-rata pada komponen isi, bahasa, dan penyajian sebesar $96,67 \%$ sehingga dapat digunakan sebagai salah satu sumber belajar siswa pada saat pembelajaran. Ada beberapa saran dari validator yang dijadikan acuan peneliti untuk merevisi, sehingga handout siswa benar-benar layak digunakan.

LKS dikembangkan bertujuan untuk melatihkan kreativitas siswa dalam merancang kegiatan penyelidikan. Validasi LKS seperti yang terlihat pada tabel 4.6 bab IV menunjukkan bahwa LKS yang dikembangkan dinyatakan valid digunakan pada tahap uji coba dengan skor rata-rata 3,58 dengan kategori valid, dengan rata-rata reliabilitas pada komponen format, bahasa, dan isi sebesar $96 \%$. Validator memberikan saran untuk memperbaiki LKS yang digunakan dalam uji coba. Saran dari validator ini dijadikan acuan peneliti untuk merevisi LKS yang akan digunakan. LKS yang digunakan terdiri dari dua buah LKS. LKS ini memuat tingkat kreativitas siswa. Tujuannya adalah agar siswa dapat meningkatkan kreativitas dengan bekerjasama secara kelompok dan dipresentasikan di depan kelas agar mendapat masukan dan tanggapan dari teman yang lain.

Berdasarkan Tabel 4.8 pada Bab IV, instrumen tes kreativitas siswa yang telah dikembangkan dapat dinyatakan valid dan dapat diimplementasikan. Terbukti dari hasil validasi instrumen yang mendapat skor 3-4 dengan kategori valid dan sangat valid dengan reliabilitas $86 \%$ dan $100 \%$.

\section{B. Kepraktisan}

Kepraktisan perangkat pembelajaran ditinjau dari keterlaksanaan rencana pelaksanaan pembelajaran (RPP). Berdasarkan hasil dari pengamatan oleh 2 pengamat. Pada pertemuan pertama, pelaksanaan pembelajaran di RPP kurang maksimal. Hal ini terjadi karena guru masih beradaptasi dengan siswa dan kurang dalam hal pengelolaan waktu. Terbukti dari penilaian dan komentar yang diberikan oleh pengamat. Setelah melakukan evaluasi, pada pertemuan berikutnya peneliti memperbaiki kekurangan yang terjadi sehingga skor rata-rata keterlaksanaan pembelajaran pada kelas XI TKR 2 dan XI TKR 3 adalah 3,8 dan 3,84 dengan kategori sangat baik dengan persentase rata-rata reliabilitas 96\%, sehingga secara keseluruhan kegiatan pembelajaran yang tercantum di RPP dapat terlaksana dengan baik.

RPP yang telah dikembangkan mengacu pada pembelajaran yang berorientasi terhadap siswa, sehingga hampir semua kegiatan pembelajaran yang terdapat dalam RPP terpusat pada siswa, antara lain mereka diminta merumuskan masalah setelah membaca handout, melakukan kegiatan di LKS dengan kreativitas mereka sendiri, kemudian aktif berdiskusi dan membuat produk. Semua kegiatan ini sesuai dengan filsafat pendidikan progrevisme yang dikembangkan oleh John Dewey yang menyatakan pendidikan berpusat pada siswa. Tujuan pendidikan merupakan rekonstruksi pengalaman yang terus-menerus, agar siswa dapat berbuat sesuatu dan mampu mengadakan penyesuaian sesuai dengan tuntutan dari lingkungan (Ornstein \& Levine, 1983).

Model pembelajaran berdasarkan masalah berbasis edutainment ini cocok digunakan untuk melatihkan kreativitas siswa karena salah satu kelebihan dari pembelajaran ini adalah materi yang diambil pada penelitian aktual dan sesuai dengan masalah dalam kehidupan sehari - hari siswa (Puskur, 2007). Hal ini akan mampu mendorong siswa untuk lebih peka terhadap masalah yang terjadi dalam kehidupan mereka serta mampu memberikan beberapa solusi untuk memecahkan masalah.

RPP yang dikembangkan dalam penelitian ini juga memuat beberapa tindakan yang dilakukan guru untuk melatihkan kreativitas siswa SMK, seperti mendorong siswa untuk berpikir secara divergen, mendidik siswa untuk bersikap toleransi dengan perbedaan pendapat di kelompok dan diskusi di kelas, serta siswa diberikan bahan, ruang dan waktu untuk melakukan proyek dengan membuat alat yang dapat memecahkan permasalahan yang diberikan oleh guru.

Kegiatan pendahuluan; guru memulai kegiatan pembelajaran di kelas dengan berdoa untuk menanamkan kesadaran dan rasa syukur atas kebesaran Tuhan. Guru menyampaikan tujuan pembelajaran dan memotivasi siswa untuk melaksanakan kegiatan pembelajaran dengan memutarkan video tentang bendungan yang jebol dan tidak dapat menahan air, kemudian siswa diminta merumuskan masalah. Siswa diberikan keleluasaan untuk memberikan apersepsi awal dan menyampaikan pendapat. Ini membuktikan bahwa guru melakukan tindakan yang mendorong kemampuan siswa dalam berdiskusi dan menumbuhkan kreativitasnya, yakni siswa didorong untuk berpikir divergen dengan cara mengutarakan pertanyaan yang mereka miliki. Sejalan dengan pernyataan tersebut Spronken-Smith (2008) mengungkapkan bahwa strategi pembuka pelajaran yang relevan dengan materi yang diajarkan adalah hal yang harus dikuasai oleh guru karena akan mempermudah peralihan yang akan dilakukan terhadap aktivitas belajar utama yang telah disiapkan. 
Tahap pendahuluan siswa diberikan motivasi agar siswa mengikuti pembelajaran dengan semangat sehingga pembelajaran yang diperoleh bermakna dan dapat meningkatkan prestasi siswa. Hal ini sejalan dengan pendapat dari Bryan Robert (2010); Patrick et al. (2007), Glynn et all (2007) yang menyatakan bahwa jika siswa termotivasi pada saat pembelajaran maka prestasi siswa dapat meningkat. Hal ini juga sejalan dengan pendapat Nur (2008) bahwa siswa yang termotivasi untuk belajar sesuatu akan menggunakan proses kognitif yang lebih tinggi dalam mempelajari materi itu, sehingga siswa itu akan menyerap dan mendengarkan materi itu dengan lebih baik.

Guru bersama siswa kemudian berdiskusi dan memilih rumusan masalah dan pendapat yang paling sesuai dengan video. Proses ini guru tidak menyalahkan atau memberikan kritik kepada siswa jika rumusan masalah dan pendapat mereka tidak sesuai dengan. Kritik di depan orang lain dapat menimbulkan munculnya sifat rendah diri. Hasilnya adalah bahwa pikiran untuk menghasilkan ide-ide yang baru mungkin menjadi hal yang begitu menakutkan. Ketakutan ini yang sering melumpuhkan kita menjadi orang kreatif.

Kegiatan diskusi mampu memberi kesempatan pada siswa untuk belajar mengungkapkan pertanyaan, mengungkapkan ide, dan berargumentasi yang berdampak pada pengetahuan dan pemahaman terhadap materi yang didiskusikan. Hal tersebut sesuai dengan teori belajar konstruktivis sosial yang menyatakan bahwa apabila guru mampu menyediakan lingkungan sosial yang memadai maka siswa dapat membangun pengetahuan dan pemahaman (Santrock, 2011).

Kegiatan inti; kegiatan selanjutnya, siswa diorganisir untuk membentuk kelompok secara heterogen dan guru membagikan handout sebagai buku pendamping siswa. Siswa diberikan waktu untuk memahami isi handout setelah itu siswa diajak berdiskusi menggunakan metode edutainment. Pada pertemuan berikutnya guru membagikan LKS dalam beberapa kelompok dan mendapat skor yang bagus dari kedua pengamat saat pertemuan pertama sampai ketiga. Siswa antusias saat diberikan LKS dan dibagi menjadi beberapa kelompok. $100 \%$ siswa merasa tertarik dengan suasana pembelajaran (sesuai angket respon siswa di Bab IV tabel 4.13) yang senantiasa melibatkan keaktifan siswa dalam pembelajaran, baik terlibat dalam penyelidikan, ataupun dalam kegiatan sosial seperti belajar dalam kelompok ini sesuai dengan teori konstruktivisme yang dikembangkan oleh Piaget dan Vygotsky.

Strategi konstruktivis sering dinamakan sebagai pengajaran yang terpusat pada siswa karena penekanan strategi ini pada siswa sebagai siswa aktif (Slavin, 2011). Piaget dan Vygotsky juga menekankan adanya hakikat sosial dari belajar dan menyarankan untuk membuat kelompok-kelompok belajar dengan kemampuan anggota kelompok yang berbeda. Ide konstruktivis menekankan pada pembelajaran kooperatif, pembelajaran berbasis kegiatan, dan penemuan.
Guru menciptakan suasana belajar yang juga mendorong siswa untuk meningkatkan kreativitasnya pada kegiatan inti. Siswa bebas mengutarakan ide-ide mereka untuk memecahkan masalah yang ada dalam diskusi. Guru juga memberikan penekanan kepada siswa agar saat temannya mengutarakan pendapat, tidak memberikan kritikan pedas apabila ada ide yang diutarakan terasa aneh. Kritikan pedas dari lingkungan akan menjadikan siswa kurang percaya diri dengan ide-ide mereka selanjutnya dan ini akan menghalangi mereka berpikir kreatif (Filasaime, 2008).

Kegiatan pembelajaran dengan menggunakan perangkat pembelajaran yang dikembangkan menjadikan siswa merasa senang dan tidak takut terhadap guru, hal tersebut dikarenakan adanya pendekatan dalam bentuk bimbingan selama proses pembelajaran berlangsung. Bimbingan ini akan semakin dikurangi tiap pertemuannya bila siswa sudah mampu mandiri. Bimbingan yang diberikan oleh guru yaitu berupa analogi dan pertanyaanpertanyaan, hal tersebut diberikan dalam melatihkan kreativitas siswa. Analogi dan pertanyaan akan menjadi bimbingan bagi siswa yang belum ahli untuk melatihkan kompetensi yang diharapkan (Harrison \& De Jong, 2005; Kirschner, 2006; Yu, 2009; Zydney, 2010).

Siswa memberikan respon positif, hal itu terlihat pada Bab IV, 93\% siswa tertarik dengan handout yang digunakan, dan $74 \%$ merasa baru dengan handout yang digunakan. Materi dan bahasa dalam handout sangat mudah untuk dicerna dan dipahami oleh siswa, 85\% menyatakan materi dan bahasa handout mudah dipahami.

Pada kegiatan inti, siswa juga diajak bekerja secara berkelompok untuk membuktikan konsep yang telah mereka pelajari dengan mengerjakan LKS 1 dan 2. LKS yang digunakan dalam penelitian ini dapat melatihkan kreativitas siswa karena siswa berusaha mendesain LKS sesuai dengan kreativitas yang mereka miliki. Mereka aktif dalam menemukan pengetahuan sendiri. Hal ini sesuai dengan tujuan pembelajaran fisika yaitu agar siswa memiliki kemampuan antara lain mengembangkan pengalaman mereka sendiri untuk dapat merumuskan masalah, mengajukan dan menguji hipotesis melalui percobaan, merancang instrumen percobaan, mengajukan dan menguji hipotesis melalui percobaan, merancang instrumen percobaan secara lisan dan tulisan (Tim BSNP, 2007).

Kegiatan penutup; guru bersama siswa mengevaluasi dengan membandingkan hasil temuan masing-masing kelompok siswa dalam pelaksanaan pengamatan, sehingga membentuk satu kesimpulan yang tepat. Guru juga memberikan refleksi kepada siswa yang berupa beberapa pertanyaan tentang materi yang telah dipelajari.

Pada tahap ini guru membimbing siswa memberikan evaluasi tentang pembelajaran yang dilakukan. Siswa diberi kesempatan untuk memberikan umpan balik terhadap seluruh proses pembelajaran yang telah dilaksanakan. Arends (2012) menyatakan bahwa 
tanpa adanya feedback, maka sedikit sekali memperoleh pengetahuan. Langkah selanjutnya siswa diarahkan untuk menyimpulkan hasil pembelajaran yang telah dilaksanakan secara bersama-sama.

Penelitian mendapat skor yang baik dari dua orang pengamat dalam aspek pengelolahan waktu pada setiap pertemuan, sehingga peneliti mendapat skor ratarata 3,8 dari pengamat dengan kategori baik.

Dalam hal pengaturan suasana kelas; pada kelas XI TKR 2 peneliti mendapat skor 3,9 dari dua orang pengamat pada pertemuan 1 sampai 4, yaitu dengan kategori baik. Pada kelas XI TKR 3 peneliti mendapat skor 3,95 dari dua orang pengamat pada pertemuan 1 sampai 4, yaitu dengan kategori baik. Hal tersebut diperkuat dengan hasil observasi langsung ke siswa saat pelaksanaan pembelajaran bahwa siswa senang karena merasa lebih aktif, dan dapat mengungkapkan idenya saat belajar. Siswa juga diajak keluar kelas saat membuat alat. Ini menjadikan siswa merasakan pembelajaran yang menyenangkan dan tidak membosankan, karena tidak melakukan kegiatan di kelas secara terus menerus. John Dewey mengungkapkan bahwa, pembelajaran sebagai proses aktif individu, bukan sesuatu yang dilakukan untuk seseorang tetapi lebih kepada sesuatu itu dilakukan oleh seseorang dan menganggap bahwa pengalaman dan penyelidikan sangat penting dalam pembelajaran bermakna (Slavin, 2011).

\section{Keefektifan}

Proses pembelajaran menggunakan model pembelajaran berdasarkan masalah berbasis edutainment pada materi fluida statis dapat berjalan dengan baik dan dapat dikatakan efektif. Keefektifan perangkat pembelajaran ditinjau dari peningkatan kreativitas siswa saat pretest dan posttest serta respon siswa.

Pemberian handout dan LKS yang dikembangkan ternyata berpengaruh terhadap efektifitas pembelajaran. Hal ini dibuktikan adanya peningkatan hasil kreativitas siswa pada ujicoba II terhadap 76 siswa kelas XI SMK Senopati Sedati jurusan otomotif. Ujicoba ini dilakukan pada dua kelas yaitu kelas XI TKR 2 dengan jumlah siswa 38 dan kelas XI TKR 3 dengan jumlah siswa 38. Tes kreativitas siswa kelas XI TKR 2 pada saat pretest diperoleh rata-rata 18,81 dengan kategori kreativitas kurang, hal ini karena siswa dinyatakan dapat mencapai kreativitas apabila nilai mencapai 75 (Mahardika, 2012). Pada saat pretest siswa mendapat nilai minimal dan belum mencapai kreativitas karena beberapa siswa masih mengalami kesulitan ketika mengerjakan soal kreativitas yang menuntut adanya variasi jawaban atau kemampuan menghasilkan banyak gagasan, selain itu pada saat siswa dihadapkan pada permasalahan yang baru, siswa masih kesulitan untuk menyelesaikan permasalahan tersebut.

Pada posttest diperoleh rata-rata 75,11 dan dinyatakan siswa mencapai kreativitas. Terjadi peningkatan kreativitas disebabkan oleh adanya pembelajaran yang memberikan kesempatan siswa untuk belajar sendiri di dalam kelompoknya sehingga memberikan ruang yang luas bagi siswa untuk mengungkapkan ide/gagasan dalam proses pembelajaran. Perhitungan $N$-gain menunjukan rata-rata 0,70 dengan kategori sedang, hal ini karena skor $N$-Gain pada rentang $0.30 \leq N$-Gain $\leq 0.70$ termasuk kategori sedang, hal ini disebabkan siswa merasa baru dengan metode pembelajaran yang dilakukan oleh peneliti dan pembelajaran sebelumnya tidak menekankan pada peningkatan kreativitas siswa. Tes kreativitas siswa kelas XI TKR 3 pada saat pretest diperoleh rata-rata 17,56 dengan kategori kreativitas kurang dan pada posttest diperoleh rata-rata 75,06 dan dinyatakan siswa mencapai kreativitas. Perhitungan $N$-gain menunjukan rata-rata 0,70 dengan kategori sedang. Hasil ini menunjukan bahwa model pembelajaran berdasarkan masalah berbasis edutainment materi fluida statis dapat melatihkan kreativitas siswa.

Skor yang digunakan berhubungan dengan originality, fluency, flexibility (Nur, 2014). Originality, fluency, flexibility, merupakan karakteristik dari kreativitas siswa. Originality ditunjukan dengan sebuah respon yang tidak biasa, unik dan jarang terjadi. Stimulasi dari ide-ide orisinil dapat diperoleh dengan cara berpikir tentang masa depan. Kelancaran (Fluency) merupakan kemampuan untuk menciptakan ide sebanyak-banyaknya. Kelancaran merupakan salah satu indikator yang kuat dari berpikir kreatif. Siswa yang memberikan banyak ide, maka semakin besar kemungkinan untuk mendapatkan ide yang signifikan. Fleksibitas (Flexibility) merupakan karakteristik yang menggambarkan kemampuan seseorang untuk mengatasi rintangan mental, mengubah pendekatan untuk sebuah masalah.

Loomas dan Kolberg (1993), menyatakan bahwa kemampuan guru menggunakan berbagai sumber utuk menciptakan suasana yang menyenangkan akan membuat siswa lebih kreatif. Kelas yang diasumsikan sebagai lingkungan yang hidup, kreatif, dan penuh tawa, maka keingintahuan dan kreativitas siswa dapat berkembang. Pembelajaran menyenangkan merupakan satu diantara cara yang dapat dilakukan untuk mencapai efektivitas pembelajaran. Dryden and Vos (2000) menjelaskan bahwa pembelajaran yang menyenangkan terdapat tiga faktor yang mempengaruhi yaitu interaksi guru dan siswa, lingkungan fisik, dan suasana belajar. Pemilihan strategi oleh guru akan meningkatkan efektivitas dan kreativitas siswa.

Hal ini sesuai dengan dengan penelitian Sulardi (2014), bahwa pembelajaran berdasarkan masalah dapat meningkatkan kemampuan berpikir kritis. Siburian (2012) juga berpendapat, bahwa penerapan model pembelajaran berdasarkan masalah berpengaruh positif untuk meningkatkan penguasaan konsep fluida statis dan kemampuan berpikir kritis siswa.

Respon siswa terhadap pembelajaran berbasis edutainment pada materi fluida statis terlihat positif, hal ini dibuktikan pada angket respon siswa yang disajikan pada Tabel 4.13 di Bab IV, menunjukan bahwa 100\% siswa yang tertarik terhadap suasana belajar, $96 \%$ siswa 
menyatakan bahwa cara guru mengajar maupun membimbing jelas, bahkan $100 \%$ siswa juga setuju jika materi pelajaran lain diterapkan dengan menggunakan pembelajaran ini. Hasil ini sesuai dengan konversi data angket respon siswa menggunakan skala Guttman yaitu interval skor $81 \%-100 \%$ berkategori sangat kuat (Riduwan, 2010).

Respon siswa terhadap instrumen penilaian tes kreativitas yang dikembangkan terlihat positif, hal ini dibuktikan pada angket respon siswa yang disajikan pada Tabel 4.13 pada Bab IV, menunjukan bahwa $85 \%$ siswa yang menyatakan mudah untuk menjawab soal kreativitas. Selama pembelajaran guru juga menciptakan suasana kelas yang mendorong siswa untuk berpikir divergen dan saling toleransi terhadap pendapat saat diskusi kelompok maupun kelas. Pemberian handout dan LKS yang juga mendorong kreativitas siswa menjadikan mereka merasa mudah dan lancar dalam pembuatan alat dan menyelesaikan soal kreativitas. Hasil ini sesuai dengan konversi data angket respon siswa menggunakan skala Guttman yaitu interval skor $81 \%-100 \%$ berkategori sangat kuat (Riduwan, 2010). Peningkatan kreativitas siswa pada ujicoba II tidak terlepas dari penguasaan siswa terhadap konsep yang mereka pelajari. Konsep tersebut mereka pelajari dan mereka dapatkan dari handout siswa yang telah dikembangkan sebelumnya sebagai buku pendamping. Materi yang diajarkan juga dekat dengan kehidupan siswa, sehingga mereka termotivasi dalam belajar sehingga siswa mudah memahami konsep-konsep tersebut.

\section{PENUTUP}

\section{A. Simpulan}

Berdasarkan hasil penelitian yang telah dilakukan, maka dapat disimpulkan bahwa perangkat pembelajaran model PBM (pembelajaran berdasarkan masalah) berbasis edutainment yang dikembangkan valid, praktis, dan efektif untuk melatihkan kreativitas siswa SMK jurusan otomotif .

\section{B. Saran}

Beberapa saran dapat dikemukakan oleh peneliti berdasarkan penelitian yang telah dilakukan yaitu penerapan rencana pelaksanaan pembelajaran sudah baik namun guru terlebih dahulu harus membekali siswa dengan keterampilan dalam kegiatan penyelidikan sehingga pembelajaran dapat berjalan dengan lancar dan tidak dibutuhkan waktu yang lama dalam membimbing siswa merancang kegiatan penyelidikan.

\section{DAFTAR PUSTAKA}

Aktam, H., Pekmez, S.E., Can, B.T., Ergin, O. (2000). Developing Scientific Creativity Test. Abstrak diperoleh dari hilal.aktamis@deu.edu.tr.

Arends, R. (2001). Learning to Teach Fifth Edition. New York: McGraw-Hill.
Arends, R. (2008). Learning to Teach. Yogyakarta: Pustaka Pelajar.

Arends, R. (2012). Learning to Teach Ninth Edition. New York: McGraw-Hill.

Arifin, Z. (2008). Metode Penelitian Pendidikan. Surabaya: Lentera Cendekia.

Arikunto, S. (2010). Prosedur Penelitian: Suatu Pendekatan Praktik. Jakarta: Rineke Cipta.

Bob, R. (2008). Why we Need to Teach $21^{\text {st }}$ Century Skills-And How to Do It. Multimedia \& Internet @ School, 15(4):10-13.

Borrich, G. (1994). Observation Skill for Effective teaching. New York: Mac Millan Publishing Company.

Bryan, Robert B. (2010). Motivation, Achievement, and Advanced Placement Intent of High School Students Learning Science. USA:Wiley Online Library

BSNP. (2014, 5 28). Instrumen Penilaian Buku Teks Pelajaran. Diambil kembali dari Badan Standar Nasional Pendidikan: http://bsnpindonesia.org/id/?p=1340.

Darmansyah. (2010). Strategi Pembelajaran Menyenangkan dengan Humor. Jakarta: PT. Bumi Aksara.

Daryanto. (2009). Panduan Proses Pembelajaran. Jakarta: AV Publisher.

Depdiknas. (2006). Model Pengembangan Silabus Mata Pelajaran. Jakarta: Badan Penelitian dan Pengembangan Pusat Kurikulum.

DePorter, Bobbi, dan Hernacki, M. (2001). Quantum Learning: Membiasakan Belajar Nyaman dan Menyenangkan. Bandung: Khaifa.

Desmita. (2006). Psikologi Perkembangan. Bandung: PT. Remaja Rosdakarya.

Rusman. (2012). Model-Model Pembelajaran Mengembangkan Profesionalisme Guru. Jakarta: PT Raja Grafindo Persada.

Firmansyah, E. (2014). Kajian Konsep Fisika. Solo: Platinum.

Giancoli, D. C. (2009). Physics for Scientist \& Engineers with Modern Physics - 4th Edition. USA: Pearson Education, Inc.

Giancoli. (2001). Fisika Jilid 1. Jakarta: Erlangga.

Glynn, S.M., Taasoobshirazi, G., \& Brickman, P. (2007). Nonscience Majors Learning Science: A Theoretical Model Of Motivation. Journal of Research in Science Teaching, 44(8), 1088-1107.

Hadaninggar, N.H. (2013). Kemampuan Metakognitif dan Kemampuan Berpikir Kritis Siswa Kelas X SMA Negeri Ngoro Jombang pada Materi Pencemaran Lingkungan Melalui Model Pembelajaran PBL. (Makalah Komprehensif Tidak Dipublikasikan). Pascasarjana Unesa.

Hake, R. (1999). American Educational Research Association's Division D, Measurement and 
Research Methodology: Analyzing Change/Gain Scores. USA: Wooland Hills

Halliday, D., Resnick, R., \& Walker, J. (2007). Fundamentals of Physics - 8th Edition. New York: John Wiley \& Sons.

Hamid, S. M. (2011). Metode Edutainment. Jogjakarta: Diva Press.

Harrison, A. \& De Jong, O. (2005). Exploring the use of multiple analogical model when teaching and learning chemical equilibrium. Journal of research in science teaching. 42 (9), 1135-1159.

Hu, W and Adey, P. (2010). A Scientific Creativity Test For Secondary School Students. International Journal Of Science Education, 24:4, 389-403.

Hu, W., Wu, B., Jia, X., Yi, X., Duan, C., Meyer, W., and Kaufman, J. (2013). Increasing Students Scientific Creativity: The Learn ti Think Intervention Program. The Journal of Creative Behavior, 47, 321.

Hurlock. E.B. (1978). Perkembangan Anak Jilid 2. Jakarta: Erlangga.

Ibrahim, M. (2005). Asesmen Berkelanjutan Konsep Dasar, Tahapan, dan Contoh. Surabaya: Unesa University Press.

Ibrahim, M. (2008). Model Pembelajaran Inovatif IPA melalui Pemaknaan. Unesa. Surabaya: Tim Balitbang Diknas.

Ibrahim, M. (2012). Pembelajaran Berdasarkan Masalah Edisi Kedua. Surabaya: Unesa University Press.

Kardi, S. (2013). Pengantar Pengembangan Kurikulum \& Rencana Pelaksanaan Pembelajaran. Surabaya: Universitas Negeri Surabaya.

Kirschner, P. A.Sweller, J. \& Clark, R. E. (2006). Why minimal gui\&ce during instruction does not work: an analysis of the failure of constructivist, discovery, problem-based, experiential, and inquiry based teaching. Educational psychologist. 41 (2), 75-86.

Kusuma, Y. (2010). Creative Problem Solving. Tangerang: Jelajah Nusa.

Lin, C., Hu. W., Adey, P. and Shen, J. (2003). The Influence of Case on Scientific Creativity. Journal of Research in Science Education, 33, 143-162.

Lin, Y.S. (2011). Fostering Creativity through EducationA Conceptual Framework of Creative Pedagogy. Creative Education, 149-155.

Mahardika. S.M. (2010). Evaluasi Pengajaran. Surabaya: Unesa University Press.

Mahtari, S. (2015). Pengembangan Prototype Buku Guru Dan Buku Siswa Ipa Dengan Penemuan Terbumbing Untuk Melatihkan Kreativitas Ilmiah Siswa. (Tesis Tidak Dipublikasikan). Pascasarjana Unesa.

Masruroh. (2015). Pengembangan Perangkat Pembelajaran Berbasis Inkuiri Terbimbing untuk Meningkatkan Kreativitas ilmiah Siswa. (Tesis Tidak Dipublikasikan). Pascasarjana Unesa.
Mohamed, A.H. (2006). Investigating The Scientific Creativity of Fifth-Grade Student. Disertation The University of Arizona.

Mulyasa, E. (2007). Kurikulum Berbasis Kompetensi. Bandung: PT Remaja Rosdakarya.

Munandar, U. (2009). Pengembangan Kreativitas Anak. Jakarta: Rineka Cipta.

Nieveen, N. (1999). Prototyping to Reach Product Quality. Kluwer Academic Publisher.

Nieeven, N. dan Plomp, T. (2007). Formative Evaluation in Educational Design Research. Enschede: Netherlands institute for curriculum development.

Novianto, B. (2014). Pengembangan Perangkat Pembelajaran Berdasarkan Masalah untuk Meningkatkan Kecakapan Akademik Siswa dan Keterampilan Proses Siswa. (Makalah Komprehensif Tidak Dipublikasikan). Pascasarjana Unesa.

Nur,M. (2011). Model Pembelajaran Berdasarkan Masalah. Surabaya: Unesa University Press.

OECD. (2009). PISA 2009 Results : Learning Trends Changes in Student Performance Since 2000 Volume V: OECD Publishing.

OECD. (2013). PISA 2012 Result: What Students Know and Can Do - Student Performance in Mathematics, Reading and Science (Volume 1). PISA. OECD Publishing. http://dx.doi.org/10.1787/9789264201118-en.

Patrick, A.O., Kpangban, E., \& Chibueeze, O.O. (2007). Motivation Effects on Test Scores of Senior Secondary School Science Students. Study Home Community Science, 1(1), 57-64.

Peraturan Menteri Pendidikan Nasional Republik Indonesia Nomer 23 Tahun 2006. Standar Proses untuk Satuan Pendidikan Dasar dan Menengah. Jakarta: Menteri Pendidikan Nasional.

Peraturan Menteri Pendidikan dan Kebudayaan Republik Indonesia Nomor 54 Tahun 2013. Standar Kompetensi Lulusan. Jakarta : Menteri Pendidikan Nasional.

Peraturan Menteri Pendidikan dan Kebudayaan Republik Indonesia Nomer 58 Tahun 2014. Pembelajaran Pada Pendidikan Dasar dan Pendidikan Menengah. Jakarta : Menteri Pendidikan Nasional.

Pisa,O.F. (2012). Pisa 2012 Data Tables, Figures, And Exhibits. Diambil Kembali Dari Nces.Ed.Gov:Https://Nces.Ed.Gov/Pubs2014/2014 024_Tables.Pdf.

Plomp.T dan Nieveen,N (2007). Formative Evaluation in Educational Design Research. Enschede : Netherlands Institute for Curriculum Development.

Prastowo, A. (2012). Bahan Ajar Inovatif. Yogyakarta: Diva Press.

Purwanto, B. (2015). Fisika KTSP. Solo: PT Serangkai Pustaka Mandiri.

Purwoko. (2010). Physics for Senior High School Year XI. Bandung: Yudhistira. 
Ratumanan, G.T. dan Laurens. (2006). Evaluasi Hasil yang Relevan dengan Memecahkan Problematika Belajar dan Mengajar. Bandung: Cv Alfabeta.

Ratumanan, G.T. dan Laurens. T. (2011). Penilaian Hasil Belajar pada Tingkat Satuan Pendidikan. Surabaya: Unesa University Press.

Ratumanan, G. T. \& Laurens. (2011). Evaluasi Hasil Belajar Tingkat Satuan Pendidikan. Surabaya: Unesa University Press.

Riduwan. 2010. Skala Pengukuran Variabel-Variabel Penelitian. Bandung: Alfabeta.

Rozaq, M. (2013). Penggunaan Metode Inkuiri untuk Mengatasi Miskonsepsi Siswa pada Materi Pokok Optika Geometri serta sebagai Upaya Meningkatkan Kreativitas Siswa di SMK Negeri 1 Lumajang. (Tesis Tidak Dipublikasikan). Pascasarjana Unesa.

Sak, U and Ayas, M.B. (2013). Creative Scientific Ability Test (C-SAT). Psychological Test and Assessment Modeling, 55, 316-329

Sanjaya, W. (2011). Perancangan \& Desain Sistem Pembelajaran. Jakarta: Kencana Prenada Media Group.

Santrock, J.W. (2008). Educational Psychology 2 Nd Edition Edisi Terjemahan. Jakarta: Kencana.

Santrock, W. J. (2011). Educational psychology. New York: McGraw-Hill Companies, Inc.

Sears, F.W. dan Zemansky, M.W. (1991). Fisika untuk Universitas 1. Jakarta: Binacipta.

Sears \& Zemansky. (2001). Fisika Universitas Edisi ke Sepuluh (Jilid 1). Jakarta: Erlangga.

Serway, R. A. (2010). Physics for Scientists and Engineers with Modern Physics, Eighth Edition. California: Brook/Cole.

Siew, N.M., Chong, C.L., Chin, K.O. (2014). Developing a Scientific Creativity Test for Fifth Graders. Problems of Education in The $21^{\text {st }}$ Century, 62, 109-123.

Siburian. (2012). Penerapan Model Pembelajaran Berdasarkan Masalah untuk Meningkatkan Penguasaan Konsep Fluida Statis dan Kemampuan Berpikir Kritis Siswa. (Tesis Tidak Dipublikasikan). Pascasarjana Unesa.

Simamora, A.B. (2012). Pengembangan Perangkat Pembelajaran Fisika Berorientasi Model Pembelajaran Berdasarkan Masalah untuk Meningkatkan Keterampilan Berpikir, Perilaku, Karakter dan Keterampilan Sosial Siswa. (Tesis Tidak Dipublikasikan). Pascasarjana Unesa.
Slavin, E. R. (2011). Educational psychology theory and practice.USA: Pearson.

Spronken-Smith, R. (2008). Experiencing the Process of Knowledge Creation: The Nature and Use of Inquiry-Based Learning in Higher Education. Journal of Research. New Zealand: University of Otago, 12-15.

Sudarma, M. (2013). Mengembangkan Keterampilan Berpikir Kreatif. Jakarta: PT Raja Grafindo Persada.

Sugiyono. (2014). Metode penelitian kombinasi (mixed methods). Bandung: Alfabeta.

Sukardi. (2008). Evaluasi Pendidikan, Prinsip \& Operasionalnya. Yogyakarta: Bumi Aksara

Sulardi. (2014). Pengembangan Model Pembelajaran Berdasarkan Masalah untuk Meningkatkan Kemampuan Berpikir Kritis. (Makalah Komprehensif Tidak Dipublikasikan). Pascasarjana Unesa.

Supeno. (2016). Model Pembelajaran Penyelesaian Masalah Argumentatif untuk Meningkatkan Hasil Belajar Fisika Kognitif Produk, Ketrampilan Proses Sains, \& Argumentasi Ilmiah Siswa SMK. (Disertasi Doktor Pendidikan tidak dipublikasikan). Universitas Negeri Surabaya.

Suyono \& Hariyanto. (2011). Belajar dan Pembelajaran: Teori dan Konsep Dasar. Bandung: PT Remaja Rosdakarya.

Thiagarajan, S., Semmel, D. S., Semmel, M.I. (1974). Instructional Development for Training Teacher of Exceptional. Minnesota: Indiana University.

Tipler, P.A. (1998). Fisika untuk Sains dan Teknik. Jakarta: Erlangga.

Ulfah, U. (2010). Pengaruh Konsep Diri, Kemandirian Pendidikan dan Kreativitas Siswa terhadap Hasil Belajar Fisika pada Siswa. (Tesis Tidak Dipublikasikan). Pascasarjana Unesa.

Yu, F. Y. (2009). Scaffolding student-generated questions: Design and development of a customizableonline learning system. Computers in Human Behavior. 25 (5), 1129-1138

Zemansky, Sears. (1994). Fisika untuk Universitas I Mekanika, Panas, Bunyi. Jakarta: Binacipta.

Zydney, J. M. (2010). The effect of multiple scaffolding tools on students' understanding, consideration of different perspectives, and misconceptions of a complex problem. Computers and Education. 54 (3), 150-159. 